\title{
CLIMATOLOGÍA DE LA BRISA MARINA EN URUGUAY
}

\author{
Gaston Manta ${ }^{1}$, Marcelo Barreiro ${ }^{1}$, Madeleine Renom ${ }^{1,2}$ \\ ${ }^{1}$ Departamento de Ciencias de la Atmósfera, Universidad de la República, Montevideo, Uruguay \\ ${ }^{2}$ Instituto Uruguayo de Meteorología, Montevideo, Uruguay
}

(Manuscrito recibido el 8 de octubre de 2019, en su versión final el 30 de marzo de 2020)

\section{RESUMEN}

La brisa marina es una circulación de mesoescala en la costa generada por el calentamiento diferencial entre la tierra y el mar. Se caracterizó la brisa marina en Uruguay utilizando datos de 8 estaciones meteorológicas costeras, así como datos satelitales y de reanálisis en el período 2011-2016. Se desarrolló un índice de identificación de la brisa marina usando la velocidad y dirección del viento a las 08:00 y 16:00 hora local. Se encontró un promedio de 60 días con brisa marina por año, que osciló entre 51 y 71 días. Ésta ocurre con el doble de frecuencia en verano, mientras que febrero y marzo muestran la mayor variabilidad interanual en ocurrencia. La brisa marina se desarrolla para valores de presión a nivel del mar entre 1000 y $1023 \mathrm{hPa}$, gradiente sinóptico de presión débil y predominio de cielos despejados. Los días consecutivos con brisa (2-7 días) generalmente se asocian con el paso de sistemas de alta presión en el Atlántico sudoccidental o situaciones de bloqueo atmosférico. Cuando hay brisa marina, tiende a ocurrir a lo largo de toda la costa uruguaya. No obstante, existen diferencias en el desarrollo de la brisa marina entre el estuario y el océano debido a las diferencias en el acoplamiento aire-mar y la orientación de la costa en relación a los vientos predominantes del noreste. En promedio, la brisa marina comienza a las 11:00 (12:00) hora local en la costa oceánica (estuarina) y tiene dirección sureste (sur), alcanzando una velocidad máxima de 7.1 $\mathrm{m} . \mathrm{s}^{-1}$ cerca de las 16:00. En varios días con brisa marina, se puede distinguir la nubosidad de tipo cúmulo asociada con el frente de la brisa.

Palabras clave: Brisa marina, Virazón, Clima de vientos, Interacción océano-atmósfera, Uruguay.

\section{SEA BREEZE CLIMATOLOGY IN URUGUAY}

\begin{abstract}
The sea breeze is a mesoscale circulation on the coast driven by the differential heating between the land and sea. Here, the sea breeze in Uruguay is characterized using data of 8 coastal meteorological stations, as well as satellite and reanalyses data sets in the period 2011-2016. A sea breeze identification index was developed using wind speed and direction at 08:00 and 16:00 local time. An average of 60 days per year was found, ranging between 51 and 71 days. Sea breeze occurs twice as often in summer, and February and March show the largest variability in the number of days with sea breeze. The sea breeze develops for sea level pressure values ranging
\end{abstract}


between 1000 and $1023 \mathrm{hPa}$, weak synoptic pressure gradient, and predominance of clear skies. Consecutive days with breeze (2-7 days) are usually associated with the passage of high pressure systems in the southwestern Atlantic or with atmospheric blocking. When there is sea breeze, it tends to occur along the entire Uruguayan coast. Nonetheless, there are differences in sea breeze development between the estuary and the oceanic regions due to the differences in air-sea coupling and the orientation of the coast in relation to the prevailing northeasterly winds. On average, the sea breeze starts at 11:00 (12:00) local time in the oceanic (estuarine) coast and has a southeasterly (southerly), reaching a maximum speed of $7.1 \mathrm{~m} . \mathrm{s}^{-1}$ near 16:00. In several cases with sea breeze, cumulus-type cloudiness can be distinguished associated with the breeze front.

Keywords: Sea breeze, Wind climate, Ocean-atmosphere interaction, Uruguay.

\section{INTRODUCTION}

The sea breeze, known in Uruguay as "virazón", is a mesoscale circulation on the coast driven by the differential heating between the land and sea. "It occurs under relatively cloud-free skies when the surface of the land heats up faster than the sea. The thermal contrast creates a local-scale pressure gradient force directed from sea to land, and a shallow layer of marine air moves inland in response" (Miller et al., 2003). Sea breeze development often depends on the prevailing synoptic situation, and its characteristics are highly variable in each location due to the shoreline curvature, topography, thermal land-ocean gradient, and geostrophic winds among others (Estoque, 1962; Simpson, 1994; Crosman and Horel, 2010).

The sea breeze is known to have a large influence in coastal air pollution (Abbs and Physick, 1992; Clappier et al., 2000), mitigating the impact of heat-waves (Papanastasiou and Melas, 2009; Ribeiro et al., 2018), wind power generation (Steele et al., 2013; Steele et al., 2015), and activities related with tourism among others, creating a strong motivation to study this phenomenon (Crosman and Horel, 2010). Its study is today even more relevant given the continuous increase in the proportion of human population living within the coastal areas (Small and Nicholls, 2003).

Describing sea breeze climatology is always an important first step to understand the temporal variations of this event (Dudouit Fichet et al., 2010). Although the phenomenon has been extensively studied in other parts of the world, there is no precedent research article in Uruguay. Thus, the objective of this research is the description of the sea breeze climatology in the Uruguayan coast.

\section{DATA AND METHODS}

In this section, we first introduce the study site, then explain the in situ and remotely sensed data used, and finish up with a description of the sea breeze identification methodology.

\subsection{Study site}

Located in southeastern South America, Uruguay is a country $600 \mathrm{~km}$ wide with more than $600 \mathrm{~km}$ of shoreline. It has large seasonality in atmospheric and nearby oceanic conditions due to the seasonal migration of the semi-permanent anticyclone and the influence of large oceanic westerly boundary currents, respectively (Peterson and Stramma, 1991). Two main coasts separated by Punta del Este (PE) cape are distinguished: To the west of $\mathrm{PE}$ it is the Rio de la Plata estuary coast, that is a shallow estuary (mostly less than $15 \mathrm{~m}$ deep), up to $230 \mathrm{~km}$ wide and a coastal orientation ranging from $\mathrm{S}$ to $\mathrm{SW}$. To the east of $\mathrm{PE}$ is the Atlantic Ocean coast with an orientation ranging from SSE to ESE (Guerrero et al., 1997; 


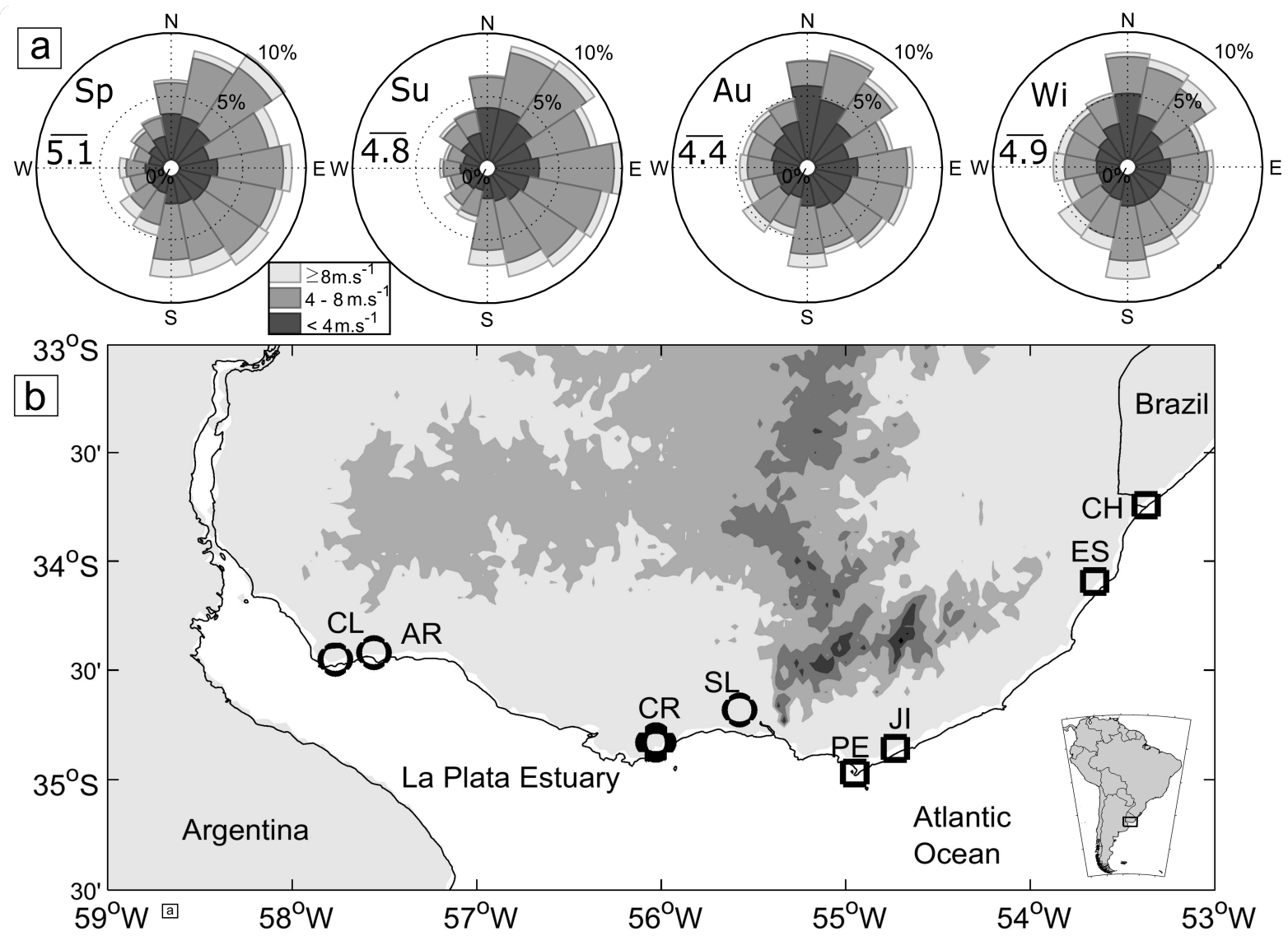

Figure 1: a) Seasonal wind roses built from hourly data from the 8 stations between 2011 and 2016. From left to right: Spring (Sp), summer $(\mathrm{Su})$, autumn $(\mathrm{Au})$ and winter $(\mathrm{Wi})$, with its corresponding mean wind speed $\left[\mathrm{m} . \mathrm{s}^{-1}\right]$. b) Study site with weather station location and code. Circles and squares distinguish stations located in the estuarine and oceanic coast respectively. Shades contours show the 100, 200 and 300 and 400 meters contours of topography from Smith and Sandwell (1997), respectively.

Fig. 1). Winds from NE prevail during most of the year, and particularly during summer, while S-SW winds have similar frequency during winter, associated with the seasonal migration of the semi-permanent anticyclone (Peterson and Stramma, 1991). The possible influence of topography in the sea breeze is very restricted, given that the highest point in Uruguay is 513 meters, and is located in the Atlantic coast 46 $\mathrm{km}$ away from the shore (Fig. 1b).

\subsection{Data}

This study uses mainly in-situ data along the coast, and is complemented with satellite and reanalysis data sets to study the regional atmospheric and oceanic conditions.

In situ data from 8 meteorological stations were used with hourly resolution covering the period 2011-2016. Three conventional stations belong to the Uruguayan Institute of Meteorology (INUMET; CL, CR and PE) and an automatic station to the Brazilian National Institute of Meteorology (INMET; CH), located less than $1 \mathrm{~km}$ away from the Uruguayan border. The other 4 automatic stations belong to the National Electric Company of Uruguay (UTE; AR, SL, JI, ES). Winds are measured at close to $10 \mathrm{~m}$ height in INUMET and INMET stations, while in the case of UTE stations wind measurements 


\begin{tabular}{cccccccc} 
Station & Code & Latitude $\left({ }^{\circ} \mathrm{S}\right)$ & Longitude $\left({ }^{\circ} \mathrm{W}\right)$ & H. $(\mathrm{m})$ & F. $(\mathrm{min})$ & Int.dir. $\left({ }^{\circ}\right)$ & Elev. $(\mathrm{m})$ \\
\hline Colonia & CL & 34.45 & 57.77 & 10 & 60 & 10 & 20 \\
Artilleros & AR & 34.42 & 57.56 & 27 & 10 & 1 & 23 \\
Carrasco & CR & 34.83 & 56.03 & 10 & 60 & 10 & 32 \\
San Luis & SL & 34.68 & 55.58 & 36 & 10 & 1 & 90 \\
Punta del Este & PE & 34.97 & 54.95 & 10 & 60 & 10 & 16 \\
Jose Ignacio & JI & 34.86 & 54.73 & 40 & 10 & 1 & 23 \\
Esmeralda & ES & 34.09 & 53.65 & 31 & 10 & 1 & 19 \\
Chui & CH & 33.74 & 53.37 & 7 & 60 & 1 & 9
\end{tabular}

Table I: Meteorological station name, code, location, height measurement $(\mathrm{H})$, sampling frequency (F), minimum interval in direction sampling (Int.dir.) and local elevation (Elev).

are taken between 30 and $40 \mathrm{~m}$ high (Table I; Fig. 1). One station, located in Carrasco International Airport (CR) have 17 years of wind data (2000-2016). All stations have at least hourly measurements between 07:00 and 18:00 (local time, UTC:-3) throughout more than $90 \%$ of the studied period and are located at a maximum distance of $12 \mathrm{~km}$ from the coast. Hourly air temperature measured at $2 \mathrm{~m}$ and sea level pressure was also used from INUMET and INMET stations.

Regarding reanalysis data, daily mean sea level pressure (SLP) fields from ERA-Interim were used with a horizontal resolution of $0.75^{\circ} \mathrm{x}$ $0.75^{\circ}$ (Dee et al., 2011). Multi-scale Ultra-high Resolution Sea Surface Temperature product of daily sea surface temperature (SST) data with $1 \mathrm{~km}$ of horizontal resolution from the "Group for High Resolution Sea Surface Temperature" (Martin et al., 2012) was also used in order to complement the absence of long term continuous measurements in the Uruguayan coast. Two SST daily time series were constructed by averaging a $10 \times 10 \mathrm{~km}$ box in front of CR and JI for the estuarine and oceanic region, respectively. As a positive temperature difference between air over the land and over the sea $(\Delta T)$ is needed for the initiation of the sea breeze (Gustavsson et al. 1995) and air temperature measurements over sea are still sparse, most studies use SST for computing the $\Delta T$. Here, the $\Delta T$ was calculated following Azorin-Molina et al. (2011) as:

$\Delta T(\check{z} C)=$ in situ hourly $2 \mathrm{~m}$ air temperature-daily SST

Also, a pressure gradient index (PGI), using ERA-Interim daily data was defined as:

$$
P G I=\left|S L P_{\text {ocean } 36 \check{z} S, 53 z ̌ W}-S L P_{\text {land } 33 \check{z} S, 56 z \check{Z} W}\right|
$$

Simple PGI indexes have been developed in order to characterize the synoptic situation (e.g. Azorin-Molina and Lopez-Bustins, 2008). Here, two points located far enough from the influence of the sea breeze were selected to capture the synoptic conditions. As PGI increases, strong synoptic winds are observed and the sea breeze does not develop.

\subsection{Sea breeze Identification Index (SBII)}

Several SBIIs have been proposed and a revision can be found in Azorin-Molina et al. (2011). Almost all SBIIs involve detecting a rapid change in wind speed (WS) and shift in wind direction (WD) at the surface or upper levels. Other usual filters include a positive $\Delta T$, and a weak surface pressure gradient. Here, a SBII index was developed considering the rapid change in WS and WD, similar to Hughes and Veron (2018), adapted to the orientation of the Uruguayan coast and the local wind climatology. The data was pre-processed before the computation of the identification index by rotating the wind 
direction $90^{\circ}$ in clockwise direction in order to avoid crossing the $360-1^{\circ}$ in the following way:

$$
\begin{aligned}
& D i r_{n e w}=\operatorname{Dir}+90 \check{z} \\
& \text { If Dir } r_{\text {new }} \geq 360 \check{z} \rightarrow \text { Dir }_{\text {new }}=\text { Dir }_{\text {new }}-360 \check{~}
\end{aligned}
$$

This modification was performed because regional climatological winds come mainly from the 1st quadrant (Fig. 1a) and the start of the sea breeze is always from the sea exposed quadrants $\left(2^{\text {nd }}\right.$ and $\left.3^{\text {rd }}\right)$. Second, when winds in the morning were weak $\left(2 \mathrm{~m} . \mathrm{s}^{-1}\right)$, conditions were considered as calm and a direction of the new $0^{\circ}$ was assigned for computation of the identification index.

$$
\operatorname{IfSpd}(08: 00)<2 m . s^{-1} \rightarrow D i r_{n e w}=0 \check{z}
$$

This adjustment deals with the fact that under weak winds conventional meteorological stations tend not to register direction and automatic ones often have a huge dispersion in the direction value. It is also common to have a near zero wind speed during the morning with a sea breeze during the afternoon. After these pre-processing steps, the necessary conditions for a positive sea breeze day are:

$$
\begin{array}{r}
\operatorname{Dir}_{\text {new }}(16: 00)-\operatorname{Dir}_{\text {new }}(08: 00)>45 \check{z} \\
\quad \operatorname{Spd}(16: 00)-\operatorname{Spd}(08: 00)>2 m . s^{-1}
\end{array}
$$

and a daily SBII vector was generated, being 1 when these conditions are met and 0 when they are not. The main weakness of this method is the possibility of a false sea breeze detection if a cold front from the $2^{\text {nd }}$ and $3^{\text {rd }}$ quadrants irrupts into the coast between 08:00 and 16:00. This is analyzed in the discussion. A comparison was also included to account for differences in the different height measurements of WD and WS of the meteorological stations (from 7 to 40 m; Fig 2a). This was possible because JI station, which has a near 3-year period with simultaneous measurements at 40,24 and $14 \mathrm{~m}$ height, shows that the daily wind cycle tends to be parallel at this heights. Accordingly, the SBII applied to JI shows similar results with 14.6, 13.7 and $11.7 \%$ of days with sea breeze at 40,25 and
14 meters of height, respectively (Fig. 2b). The main advantage of this index is that it had a $92 \%$ of data coverage for 8 coastal stations all along the Uruguayan coast during 6 consecutive years, being an unprecedented database. Finally, a "generalized" sea breeze day index (GSBII) was calculated, which defined positive for days when at least half of the stations with measured data had positive SBII values. When this index was positive, the day was considered with sea breeze development all along the Uruguayan coast. Annual and monthly means were computed for SBII and GSBII.

\section{RESULTS}

\subsection{Sea breeze climatology}

An average of 60 days with sea breeze per year for all stations were found between January 1, 2011 and December 31, 2016 (355 days in 2192), with a standard deviation of 7 days per station and also per year. Of the 355,312 days had positive GSBII corresponding to an annual average of 52 events per year. This similarity suggests that when sea breeze develops it is likely to occur in the majority of the coastline. The month with more sea breeze days is January, with an average above 8 days per month, while June is the one with fewest events, below 3 days per month (Fig. 3). Sea breeze is twice more likely to occur during summer (Dec-Mar) than in the rest of the year. This pattern is also observed in the 17-year long record in CR station, where 7-8 days with sea breeze per month in summer were observed and 3-4 events in winter months. While January is the month with highest average during the 6 year period, it has a low interannual variability. February and March tend to have the highest variability, and the maximum number of sea breeze days per month were observed during these months. The largest number of sea breeze days occurred during March 2015, when 17 consecutive days were recorded in a single station, with a mean of 12 days with sea breeze between the 8 stations that month (Fig. 3). An atmospheric blocking configuration was responsible for maintaining the right conditions for sea breeze development (not shown). 

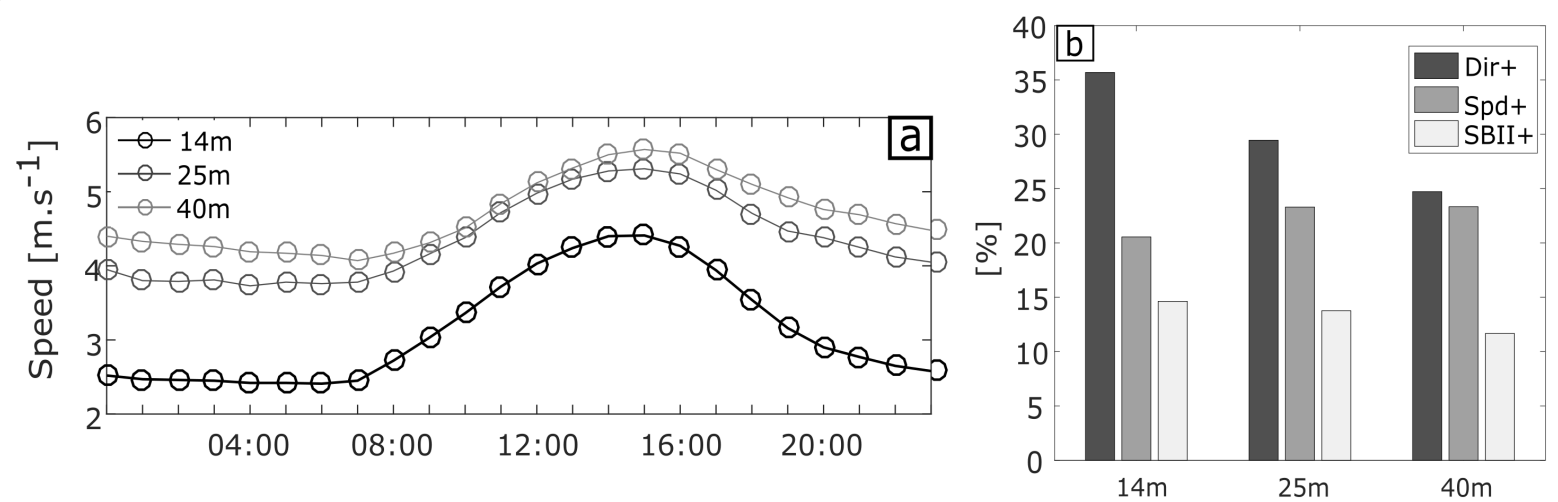

Figure 2: a) Hourly average of speed $\left[\mathrm{m} \cdot \mathrm{s}^{-1}\right]$ in JI coastal station in Uruguay at three different heights of measurement $(40,25$ and $14 \mathrm{~m})$. Measurements at 16:00 and 08:00 were used to subtract in the sea breeze identification index (SBII). b) SBII for a period with simultaneous measurements at different heights in JI. The percentage of days that passed the direction (Dir+) and speed $(\mathrm{Spd}+)$ condition of the SBII (SBII+), respectively.

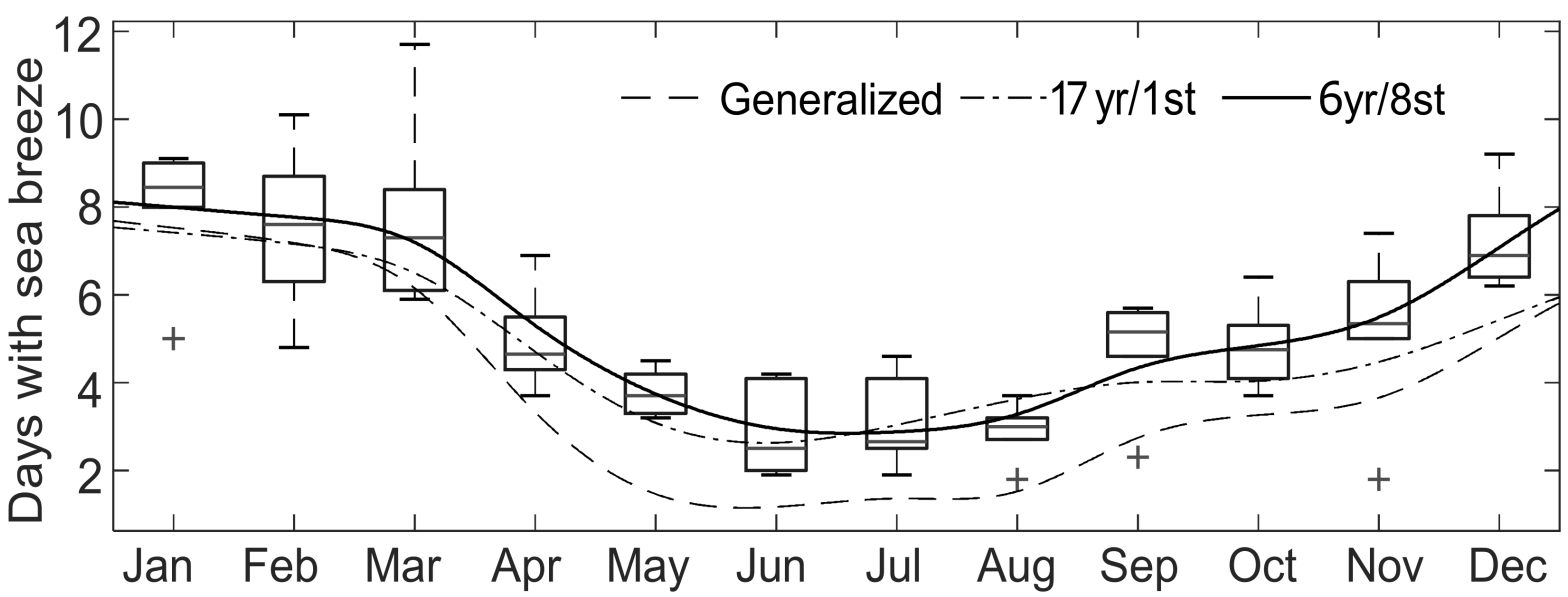

Figure 3: Sea breeze climatology in the Uruguayan coast. Box plot and solid line show the average from 8 stations along the Uruguayan coast for a 6 year period. Dashed line is the climatology of generalized sea breeze (days when at least half of the stations registered sea breeze). Dash-dot line is the climatology for 17 years in CR station. The central mark is the median, the edges of the box are the $25^{\text {th }}$ and $75^{\text {th }}$ percentiles, and the whiskers extend to the most extreme data points the algorithm considers not to be outliers, and the outliers are plotted individually.

\subsection{Sea breezes during summer}

Given that sea breeze events tend to occur mainly during summer and that the atmospheric dynamics in the region is different in winter, mainly dominated by frontal systems, than in summer where there is a higher influence of the semi-permanent anticyclone of the South
Atlantic (Garreaud and Aceituno, 2007), for the rest of the analysis only the summer period was considered. 

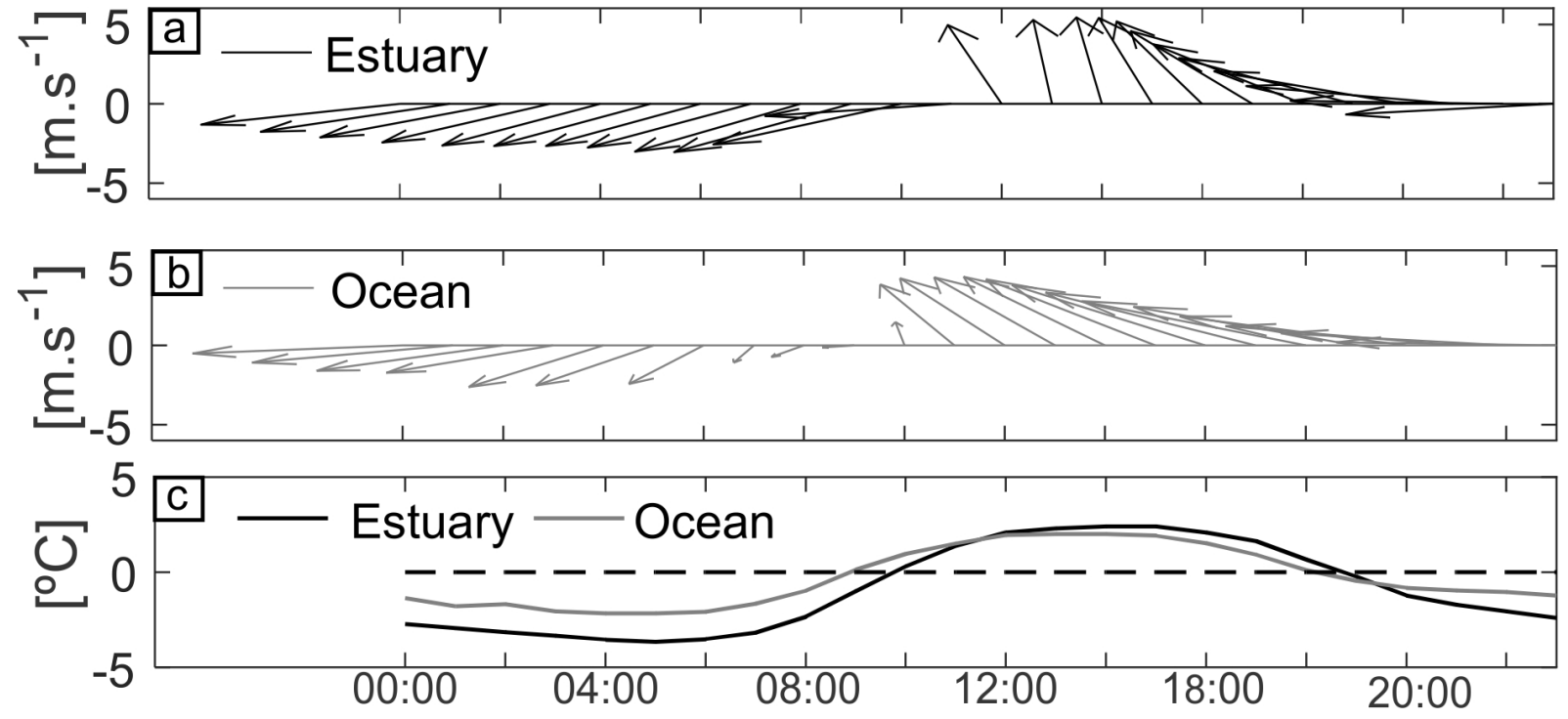

Figure 4: Daily cycle of winds [m.s $\left.{ }^{-1}\right]$ during summer in: a) Estuary and b) Ocean. c) Difference between air and water temperature $\left[\Delta T,{ }^{\circ} \mathrm{C}\right]$ in the estuary and oceanic region during summer, respectively. Wind data and air temperature from all estuarine and oceanic stations were used to compute each panel respectively. For the SST, representative time series for each region was taken (see methods).
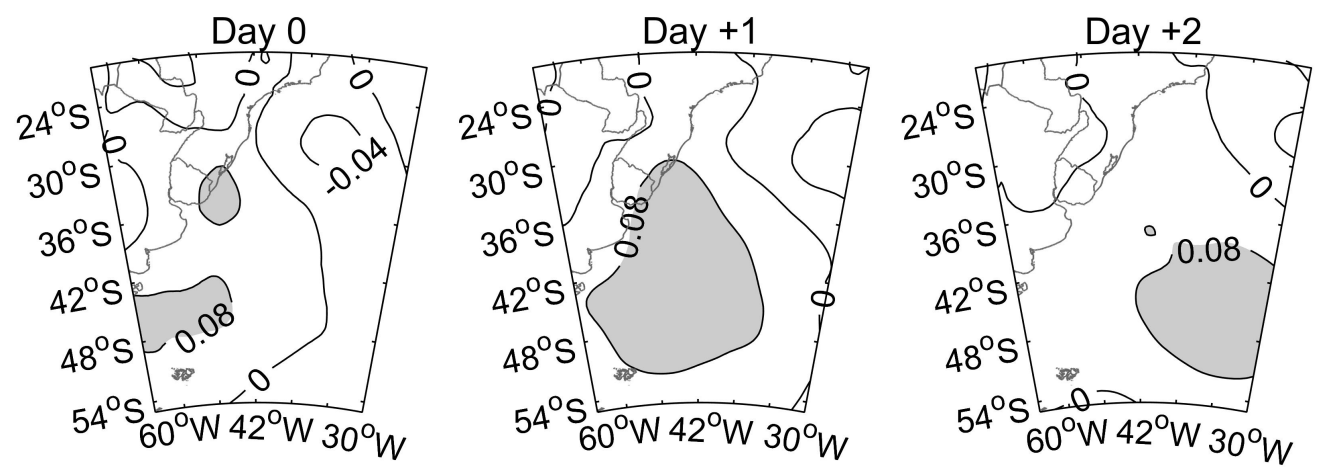

Figure 5: Correlation between daily Sea level Pressure from ERA-Interim and same day generalized sea breeze events in Uruguay (left panel), and lag correlation for one and two days after the GSBII days (middle and right panels). Shaded areas show areas with significant correlation (t-test; $p<0,05, n=728$ ).

\subsection{Differences in the sea breeze between the estuary and oceanic coast}

The sea breeze depends on the land-sea air temperature contrast. As the mean conditions of sea surface temperature in the estuary and oceanic regions are different because the former is shallower and thus warmer during summer, this will result in different land-sea air temperature contrasts. Moreover, the orientation of the coast in relation to the prevailing winds blowing from the northeast will also play a role. The daily cycle in the oceanic and estuarine coast is dominated by a strong sea-land-breeze, as found by Berri et al. (2010). The sea breeze starts between 10:00 and 11:00 (local time) in the oceanic region (east of PE) and between 11:00 and 12:00 in the estuary (west of PE; Fig. 4a and 4b). One main reason for the earlier start in the oceanic 

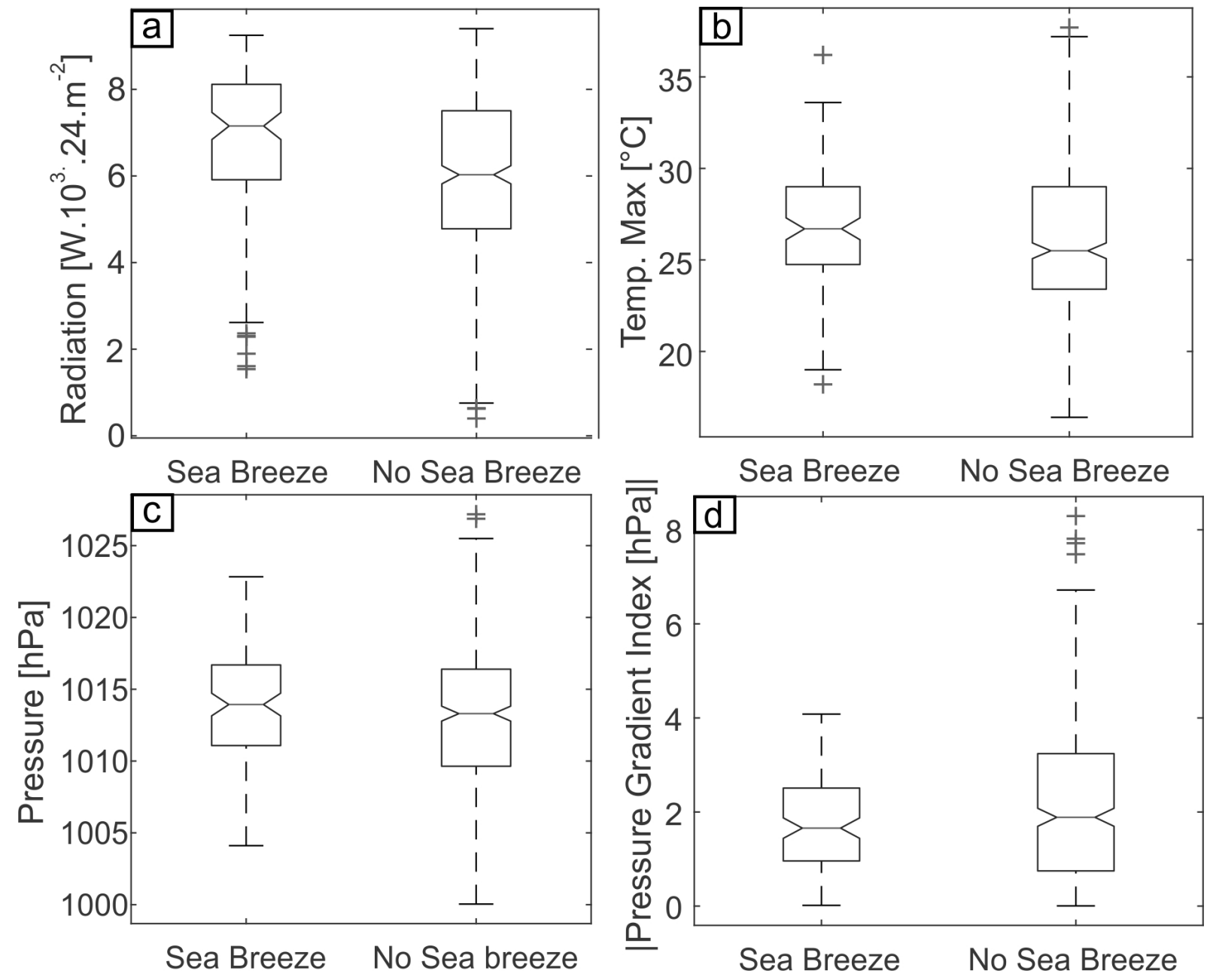

Figure 6: Box plot derived from Kruskal-Wallis test for summer days between 2011 and 2016 $(n=728)$ in Uruguay with or without sea breeze for: a) Daily cumulative in situ radiation $(p<0,05)$, b) Daily maximum temperature $(p<0,1)$. c) Pressure in CR $(\mathrm{p}<0.1)$, d) Pressure Gradient Index $\left(P G I=S L P_{\text {ocean } 36 z ̌ s, 53 z ̌ W}{ }^{\smile} S L P_{\text {land33žS,56žW }} ; p<0,05\right)$. Box limits extend to the median, $25^{\text {th }}$ and $75^{\text {th }}$ percentile. Whiskers extend to almost all data range, except for sum symbols automatically considered as outliers.

region is that the $\Delta T$ there becomes positive at 9:00, but only an hour later, at 10:00, in the estuary (Fig. 4c). This is mainly because the oceanic region tends to be colder than the estuary during summer. No significant differences were found in sea breeze days per month between estuary and ocean, consistent with the fact that sea breeze tends to develop along all the coast when it happens.

\subsection{Synoptic conditions favoring sea breeze during summer}

A correlation analysis between daily mean SLP in the Southwestern Atlantic Ocean (SAO) and days with the occurrence of generalized sea breeze events in the Uruguayan coast during summer (1s and 0s daily vector for days with and without sea breeze, respectively) was done, both for the same day and the 3 days before and after the event. Statistical significance was tested with a two tailed Student t-test $(\mathrm{p}<0.05$, $\mathrm{n}=728$ ). This analysis shows the establishment 
and eastward propagation of a high pressure system in the SAO for zero lag and up to two days lag (Fig 5). No significant relationship was observed the days before.

\subsection{Characteristics of a sea breeze day during summer}

The non-parametric, one-way ANOVA on ranks, Kruskal-Wallis test (Hecke, 2012) was computed in order to compare the behavior of several variables (some not normally distributed) during summer days with and without sea breeze. In the analysis, hourly data was considered for all stations with measurements of temperature, pressure and radiation, while PGI daily data was used from ERA-Interim. The hourly cumulative sum of radiation per day during sea breeze days is $281.5 \mathrm{~W} . \mathrm{m}-2$, $38.3 \mathrm{~W} . \mathrm{m}-2$ higher than those days without sea breeze, showing that a more cloud-free sky is expected during days with sea breeze (Fig. 6a; $p<0,05$ ). In situ daily maximum temperature and SLP show a similar behavior, with a more restricted range of variability those days with sea breeze in comparison with days without sea breeze, with mean values marginally significant higher during days with sea breeze $(\mathrm{p}<0.01)$. Almost no extreme value above $33^{\circ} \mathrm{C}$ and $1025 \mathrm{hPa}$ is observed during days with sea breeze (Fig. 6b and 6c). Finally, the PGI mean is $1.7 \mathrm{hPa}$ during days with sea breeze, $0.4 \mathrm{hPa}$ below the mean of non-sea breeze days $(\mathrm{p}<0.05)$, with $2.5(3.3)$ and $4.1(6.7) \mathrm{hPa}$ the $75^{\text {th }}$ percentile and the maximum registered the days with (without) sea breeze, respectively.

\subsection{Case of study}

Figure 7 shows six consecutive sea breeze days in the Uruguayan Atlantic coast between 11 and 16 January 2013 at JI station. This meteorological station sampled every 10 minutes wind speed and direction, temperature and solar radiation. During this period, the synoptic conditions were dominated by a high pressure system in the $\mathrm{SAO}$ and a thermal low pressure in subtropical South America, with an average of $1015 \mathrm{hPa}$ over Uruguay, $2 \mathrm{hPa}$ above the summer mean, and a weak PGI of $1.41 \mathrm{hPa}$ on average, 0.37
hPa below the summer mean (not shown). This led to synoptic winds from N-NE observed at night during the majority of the period. However, during the day $\mathrm{E}$ and $\mathrm{SE}$ winds are observed at midday and noon associated with the sea breeze (Fig 7a). During these days, the instant wind rotation related to the sea breeze began between 10:10 to $12: 20$ and reached its maximum speed from 13:20 to 15:10 along the different days (local time, UTC-3) with maximum speed values from 5.4 to $6.7 \mathrm{~m} . \mathrm{s}^{-1}$ (Fig $7 \mathrm{~b}$ and $7 \mathrm{c}$ ). Also during these days, the air temperature exceeded for the first time in the day the SST between 08:10 and 13:10 the earliest and latest respectively, and this moment ranged from 10 minutes to 3 hours before the sea breeze onset. In the majority of the cases the maximum air temperature of the day was observed just before the beginning of the sea breeze, followed by an instant drop of up to $1.5^{\circ} \mathrm{C}$ (Fig $7 \mathrm{~d}$ ). Finally, the solar radiation shows a "clean" curve associated with clear sky in the majority of the days (Fig 7e). Five out of the 6 days had a cloud-free morning, and an instant drop in the radiation curve can be seen on 11, 13 and 15 of January near the onset of the sea breeze, probably as a consequence of the passage of cumulus-type clouds associated with the sea breeze front (Fig 7e). This front can be seen in satellite images penetrating up to near 50 $\mathrm{km}$ inland, but not in all cases. Figure $7 \mathrm{f}$ shows an example of the sea breeze front penetrating inland from Aqua MODIS (Savtchenko et al., 2004).

\section{DISCUSSION}

This is the first detailed characterization of the sea breeze in Uruguay with a previous construction of an unprecedented coastal database. Our analysis shows that there are about 60 days with sea breeze per year in Uruguay, ranging between 51 and 71 in the 6-year study period, occurring twice as often during summer compared to the rest of the year. This result is similar to that found by other authors in different regions of the world. For example, Azorín-Molina et al. (2011) found in the Bay of Alicante 475 sea breeze events with 

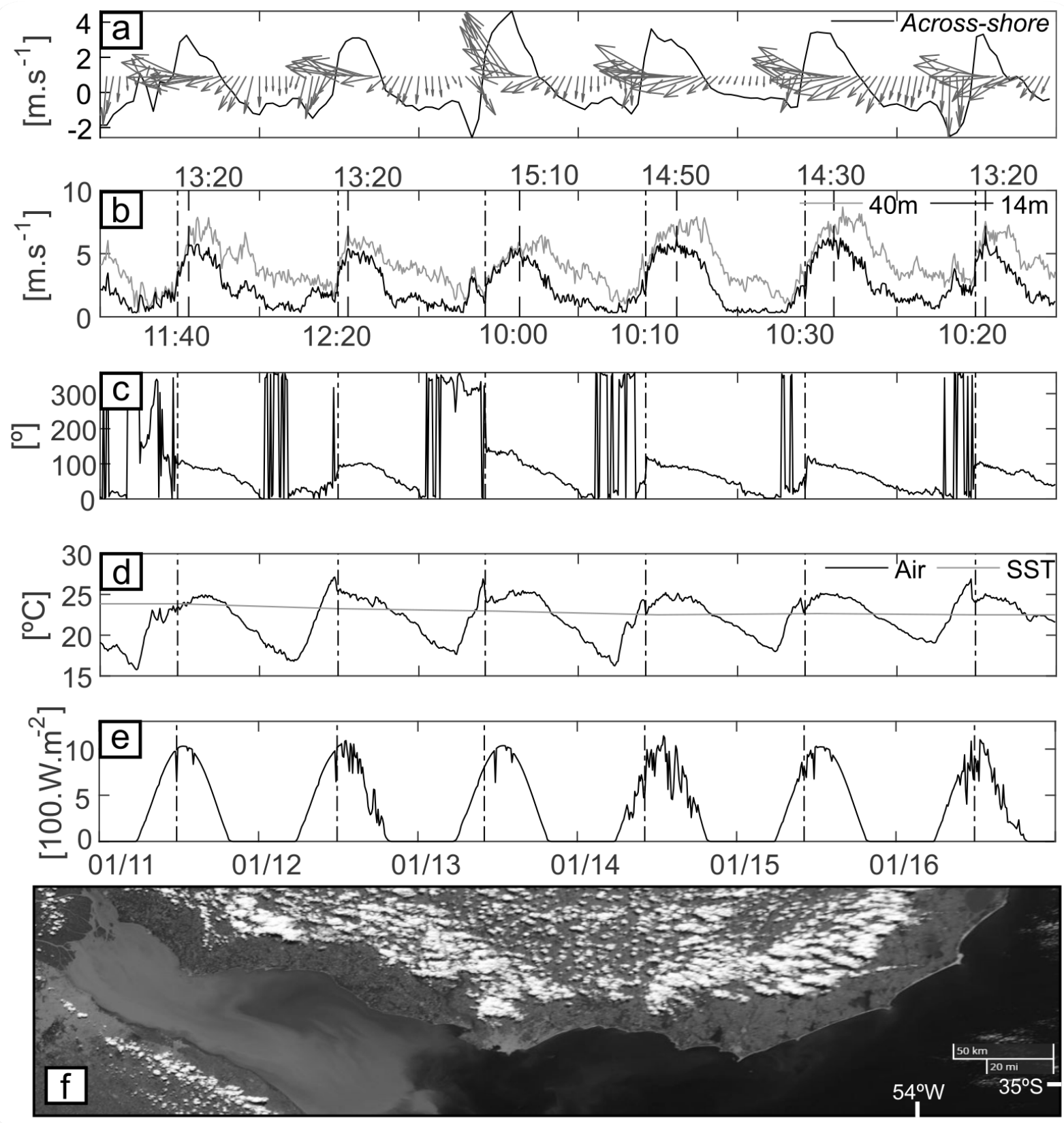

Figure 7: Six days with sea breeze in the Uruguayan coast. 10 minute- records of meteorological variables between 11 and 16 of January 2013 at JI station in the Uruguayan oceanic coast. a) Wind (arrows) and across-shore velocity $\left[\mathrm{m} \cdot \mathrm{s}^{-1}\right]$. b) Wind speed at 40 and $14 \mathrm{~m}\left[\mathrm{~m} \cdot \mathrm{s}^{-1}\right]$. Dashed-dot line shows the time onset of the sea-breeze and dashed line shows the time of daily maximum of wind speed at $14 \mathrm{~m}$ (GMT -3). c) Wind direction [o] at 40m. d) Air and sea surface temperature (SST) $\left[{ }^{\circ} \mathrm{C}\right]$ e) Solar radiation $\left[\mathrm{W}^{-m^{-2}}\right]$. f) Snapshot of the sea breeze front seen from satellite MODIS Aqua on 22 February 2015 at midday local time (16:00 UTC).

an automatic index and 1414 with a manual one for the same 6 years of study. Also, Pazandeh et al. (2016) found an annual average of $27 \%$ of days with sea breeze, $42 \%$ in summer and
$10 \%$ in winter, analyzing in situ data during the period between 1955 and 2008 in Adelaide, Australia. The reported frequency of sea breeze days tends to be highly variable due to the region, 
the climate, time of the year, and the distance from the coast considered, but it also depends on the SBII used. For example, Cisneros and Piccolo (2011) in Monte Hermoso in Argentina, near $600 \mathrm{~km}$ away from Uruguay, found 40 sea breeze events between 2007 and 2010 using a manual identification method from in situ data and synoptic charts. Hughes and Veron (2018) found $70-80 \%$ of sea breeze days in Delaware during summer, defined as days when at least one station registered the sea breeze, but that value decreased by half in stations more than $1 \mathrm{~km}$ away from the coast. In addition, a large variability in sea-breeze frequency between neighboring coastlines of up to a factor of 3 was reported by Steele et al (2015) in England, making comparisons extremely difficult.

\subsection{SBII performance}

The SBII demonstrated the capacity to identify sea breeze days with just WS and WD at 08:00 and 16:00 measured from 7 to $40 \mathrm{~m}$ of height, being highly efficient in the trade-off between the input requirements and the correct identification of a sea breeze day. The skill of the SBII was investigated using synoptic maps to check when sea-breeze conditions were incorrectly identified from station observations. The days with "false positive" were mainly those days when a cold-front irrupts into the coast between 08:00 and 16:00. To correctly discard these days, a good complement to the SBII would be the SLP pressure field, the PGI, or a 24 hour- coverage of wind data in the meteorological station. For example, taking an arbitrary PGI threshold value of $3 \mathrm{hPa}$ which characterizes a strong synoptic wind situation that suppresses the development of the sea breeze, like several sea breeze identification algorithms do (references in Azorin-Molina et al., 2011), then the discarded "false positives" would be $4 \%$ of the cases. The 24 hour-coverage of WD and WS would also allow to detect whether there is a decrease in the WS and rotation of WD when the sea-breeze ends near sunset, or if the WS and WD remain similar due to the cold front intrusion, but 2 of the conventional stations used here did not register data between 17:00 and 06:00.

The onset time of the sea breeze showed to be highly variable, from 09:00 to 16:00, and this needs to be taken into account in a SBII. With higher $\Delta T$ the sea breeze starts earlier, while with synoptic winds coming from land it starts later (Simpson, 1994). SST is not a good input for a SBII because the $\Delta T$ in this region tends to be positive the majority of the days of the year, being an uninformative filter. An instant drop in the temperature and an increment of relative humidity and dew-point with the onset of the sea breeze were also observed but not in all cases and, since humidity is not measured in all stations, we did not use this variable in the SBII. The identification of the sea breeze front in satellite images, as previously done by Planchon et al. (2006), was also not a good SBII method in this region. More than 60 SBII positive days were visually checked from $\mathrm{GOEs}^{-1} 3$ at http: //satelite.cptec.inpe.br/acervo/ and the sea breeze front did not develop in near half of the days. Nevertheless, when the sea breeze front developed, the visual check allowed to detect that the sea breeze can penetrate inland as far as $55 \mathrm{~km}$ from the coast.

The spatial pressure gradient has been used in the index to identify sea breeze events (e.g. Steele et al., 2015). Azorin-Molina and Lopez-Bustins (2008) used the index of pressure between Spain and Italy called "WeMOI" (Western Mediterranean Oscillation Index), originally used to study rainfall, as a good indicator for the development of the sea breeze. They found that for the interval between -1 and $1 \mathrm{hPa}$ of the index (weak gradient), $56 \%$ of days without breeze and $18.7 \%$ of days with breeze were excluded. In this study we found that no sea breeze developed in Uruguay when the PGI absolute value was higher than $4 \mathrm{hPa}$ and the $75 \%$ of the days with sea breeze were had a PGI below $2.5 \mathrm{hPa}$.

Finally, Arrit (1991) showed that in several days a "hidden" sea breeze can be observed embedded in the synoptic flow. We tested this assumption using the long time series in $\mathrm{CR}$, and created 
a SBII for those hidden sea breeze days. This was done through the application of a high-pass filter to the original SBII, which consisted in subtracting a 24 hour-centered moving average to $\mathrm{u}$ and $\mathrm{v}$ vectors. In this way the synoptic flow is filtered out and we assume that the residual winds are WS and WD associated with the sea breeze. Also, the WS condition for the SBII was relaxed from 2 to $1 \mathrm{~m} . \mathrm{s}^{-1}$ as the average WS decreased by half after removing the moving mean. This technique requires a 24 hour coverage of data and it is not possible to contemplate height measurement differences, as wind shear increases during the night, leading to substantial differences in the removal value of the 24 hour-moving mean. The analysis performed to CR station revealed a similar amount of hidden sea breeze days (near 60 events per year) with respect to "pure" sea breeze days, after removing these days previously identified.

\section{CONCLUSIONS}

An average of 60 days per year was found in the Uruguayan coast, with an interannual variability ranging between 51 and 71 days in six years of study. Sea breeze occurs twice as often in summer, months when the land-sea contrast in maximum temperature is largest and a lower atmospheric pressure gradient develops. March and November show the largest year to year variability in the number of days with sea breeze. The sea breeze develops at intermediate sea level pressures (high with respect to the summer average), weak land-sea pressure gradient, and predominance of clear skies. Breezes do not occur at pressures higher than $1025 \mathrm{hPa}$. Consecutive days with breeze (2 to 7 days) are usually associated with the passage of high pressure systems in the southwestern Atlantic or with atmospheric blocking. When there is sea breeze, it tends to occur along the entire Uruguayan coast. Nonetheless, there are differences in sea breeze development between the estuary and the oceanic regions due to the differences in air-sea coupling and the orientation of the coast in relation to the prevailing northeasterly winds (during summer). On average, the sea breeze starts at 11:00 (local time) in the oceanic coast and has a southeasterly direction while in the estuary it starts at 12:00 and has a southerly direction, reaching a maximum speed of $7.1 \mathrm{~m} . \mathrm{s}^{-1}$ between 16:00 and 17:00. In several cases with sea breeze, cumulus-type cloudiness can be observed, associated with the breeze front that grows and penetrates inland up to about $55 \mathrm{~km}$ at sunset.

Agradecimientos: SST data was downloaded from https://podaac.jpl.nasa.gov/ and ERA-Interim from http://apps.ecmwf.int/ Authors also acknowledge Brazilian and Uruguayan National Institutes of Meteorology and Uruguayan National Electric Company (UTE) for the free data provided. GM received funding from the National Research and Innovation Agency of Uruguay (POS_NAC_2015_1_109662). The authors acknowledge Hernán Bechis and another anonymous referee for their valuable comments.

\section{REFERENCIAS}

Abbs, D. and Physick, L. (1992): Sea-breeze observations and modelling: a review. Australian Meteorological Magazine, 41, 7-19. Arritt, R. (1993): Effects of the large-scale flow on characteristic features of the sea breeze. Journal of Applied Meteorology, 32, 116-125.

Azorin-Molina, C. and Lopez-Bustins, J. (2008): An automated sea breeze selection technique based on regional sea-level pressure difference: WeMOi. International Journal of Climatology, 28, 1681-1692.

Azorin-Molina, C., Tijm, S. and Chen, D. (2011): Development of selection algorithms and databases for sea breeze studies. Theoretical and applied climatology, 106, 531-546.

Berri, G. J., Sraibman, L., Tanco, R. A., and Bertossa, G. (2010): Low-level wind field climatology over the La Plata River region obtained with a mesoscale atmospheric boundary layer model forced with local weather observations. Journal of Applied Meteorology and Climatology, 49, 1293-1305.

Cisneros, M. and Piccolo, M. (2011): 
Caracterizaciónde la Brisa marina en Monte Hermoso, Argentina. Estudios Geográficos, 72(271), 461-475.

Clappier, A., Martilli, A., Grossi, P., Thunis, P., Pasi, F., Krueger, B. C., ... and van den Bergh, H. (2000): Effect of sea breeze on air pollution in the greater Athens area. Part I: numerical simulations and field observations. Journal of Applied Meteorology, 39, 546-562.

Crosman, E. and Horel, J. (2010): Sea and lake breezes: a review of numerical studies. Boundary-layer Meteorology, 137, 1-29.

Dee, D. P., Uppala, S. M., Simmons, A. J., Berrisford, P., Poli, P., Kobayashi, S., ... and Bechtold, P. (2011): The ERA-Interim reanalysis: Configuration and performance of the data assimilation system. Quarterly Journal of the royal meteorological society, 137, 553-597.

Dudouit Fichet, A., Quénol, H., Planchon, O., and Douvinet, J. (2010): Analysis of local wind systems in the Caen region (Lower Normandy, France). International Journal of Climatology: A Journal of the Royal Meteorological Society, 30, 406-417.

Estoque, M. (1962): The sea breeze as a function of the prevailing synoptic situation. Journal of the Atmospheric Sciences, 19(3), 244-250.

Garreaud, R. D., and Aceituno, P. (2007): Atmospheric circulation over South America: mean features and variability. The physical geography of South America. Oxford University Press, Oxford, England.

Guerrero, R., Acha, E., Framin, M., and Lasta, C. (1997): Physical oceanography of the Río de la Plata Estuary, Argentina. Continental Shelf Research, 17, 727-742.

Gustavsson, T., Lindqvist, S., Borne, K., and Bogren, J. (1995): A study of sea and land breezes in an archipelago on the west coast of Sweden. International Journal of Climatology, 15(7), 785-800.

Hecke, T. V. (2012): Power study of anova versus Kruskal-Wallis test. Journal of Statistics and Management Systems, 15, 241-247.

Hughes, C. P., and Veron, D. E. (2018): A Characterization of the Delaware Sea Breeze Using Observations and Modeling. Journal of Applied Meteorology and Climatology, 57, 1405-1421.

Martin, M., Dash, P., Ignatov, A., Banzon, V., Beggs, H., Brasnett, B., ... and Grumbine, R. (2012): Group for High Resolution Sea Surface temperature (GHRSST) analysis fields inter-comparisons. Part 1: A GHRSST multi-product ensemble (GMPE). Deep Sea Research Part II: Topical Studies in Oceanography, 77, 21-30.

Miller, S.., Keim, B., Talbot, R. and Mao, H. (2003): Sea breeze: Structure, forecasting, and impacts. Reviews of Geophysics, 41(3).

Papanastasiou, D. K., and Melas, D. (2009): Climatology and impact on air quality of sea breeze in an urban coastal environment. International Journal of Climatology: A Journal of the Royal Meteorological Society, 29, 305-315.

Pazandeh M., Walker, D. y Crowther, J. (2016): Sea breeze characteristics on two sides of a shallow gulf: study of the Gulf St Vincent in South Australia. Meteorological Applications, 23, 222-229.

Peterson, R. and Stramma, L. (1991): Upper-level circulation in the South Atlantic Ocean. Progress in Oceanography, 26, 1-73.

Planchon, O., Damato, F., Dubreuil, V., y Gouéry, P. (2006): A method of identifying and locating sea-breeze fronts in north-eastern Brazil by remote sensing. Meteorological Applications, 13, 225-234.

Ribeiro, F. N., de Oliveira, A. P., Soares, J., de Miranda, R. M., Barlage, M., and Chen, F. (2018): Effect of sea breeze propagation on the urban boundary layer of the metropolitan region of Sao Paulo, Brazil. Atmospheric Research, 214, 174-188.

Savtchenko, A., Ouzounov, D., Ahmad, S., Acker, J., Leptoukh, G., Koziana, J., and Nickless, D. (2004): Terra and Aqua MODIS products available from NASA GES DAAC. Advances in Space Research, 34, 710-714.

Simpson, J. E., (1994): Sea Breeze and Local Winds. Cambridge University Press.

Small, C., and Nicholls, R. J. (2003): A global analysis of human settlement in coastal zones. 
Journal of Coastal Research, 584-599.

Smith, W., and Sandwell, D. (1997): Global sea floor topography from satellite altimetry and ship depth soundings. Science, 277, 1956-1962.

Steele, C. J., Dorling, S. R., Von Glasow, R., and Bacon, J. (2013): Idealized WRF model sensitivity simulations of sea breeze types and their effects on offshore windfields. Atmospheric Chemistry and Physics, 13, 443. Steele, C., Dorling, S., von Glasow, R. and Bacon, J. (2015): Modelling sea-breeze climatologies and interactions on coasts in the southern North Sea: implications for offshore wind energy. Quarterly Journal of the Royal Meteorological Society, 141, 1821-1835.

Este es un artículo de acceso abierto distribuido bajo la licencia Creative Commons, que permite el uso ilimitado, distribución y reproducción en cualquier medio, siempre que la obra original sea debidamente citada. 